\title{
Leaf litter decomposition in western Iberian forested wetlands: lentic versus lotic response
}

\author{
Ana Sampaio ${ }^{1, *}$, Patricia Rodríguez-González ${ }^{2}$, Simone Varandas ${ }^{3}$, Rui Manuel Cortes ${ }^{3}$ and \\ Maria Teresa Ferreira ${ }^{2}$ \\ ${ }^{1}$ Centro de Estudos Tecnológicos do Ambiente e da Vida (CETAV), Universidade de Trás-os-Montes e Alto \\ Douro, Apartado 1013, 5001-801, Vila Real, Portugal. \\ 2 Departamento de Engenharia Florestal, Instituto Superior de Agronomia, Tapada da Ajuda, 1349-017, Lisboa, \\ Portugal. E-mail: patri@isa.utl.pt \\ ${ }^{3}$ Centro de Estudos em Gestão de Ecossistemas (CEGE), Universidade de Trás-os-Montes e Alto Douro, \\ Apartado 1013, 5001-801, Vila Real, Portugal \\ * Corresponding author: asampaio@utad.pt
}

Received: 22/2/07 Accepted: 11/10/07

\begin{abstract}
Leaf litter decomposition in western Iberian forested wetlands: lentic versus lotic response

Leaf litter breakdown is frequently used to measure both structural and functional integrity in aquatic ecosystems. Forested wetlands are interface systems that received little attention, especially in the Iberian Peninsula. The present study compares the decomposition of alder and willow in two biotopes (lentic and lotic) located in two different sites (Caxarias and Alpiarça). Litterbags were used to compare decomposition among the different treatments. Throughout decay, dry weight loss, nitrogen and phosphorus content, microbial community physiological profiles, microbial and macro-invertebrate colonization were measured at days $2,4,8,16,32$ and 64 . Decomposition rates ranged from intermediate to rapid for alder $\left(0.006\right.$ day $^{-1}$ to $\left.0.0338 \mathrm{day}^{-1}\right)$ and slow to rapid for willow $\left(0.0024\right.$ day $^{-1}$ to $\left.0.0272 \mathrm{day}^{-1}\right)$, depending on site and biotopes type. The combined effects biotope $\times$ time was significant for heterotrophs $(P<0.05)$, molds $(P<0.05)$ and yeasts $(P<0.001)$. The analysis of average well colour development (AWCD), richness (R) and Shannon-Wiener index $\left(\mathrm{H}^{\prime}\right)$ based on the oxidation of carbon and nitrogen sources by the microbial community, showed differences between the two biotopes, lotic and lentic, and sites. These differences were also shown by the principal component analysis (PCA). Moreover, the macroinvertebrate communities clearly distinguished between lentic and lotic systems. The invertebrates belonging to Plecoptera, Ephemeroptera and Trichoptera were absent from lentic habitats.
\end{abstract}

Key words: Leaf litter, forested wetlands, decomposition, lotic, lentic, microorganisms, macroinvertebrates.

\section{RESUMEN}

Descomposición de la hojarasca en humedales boscosos de la zona occidental Ibérica: Respuesta lenítica frente a lótica

La descomposición de hojarasca se utiliza frecuentemente para medir la integridad estructural y funcional en los sistemas acuáticos. Los humedales arbolados son sistemas de transición que han recibido escasa atención especialmente en la Península Ibérica. El presente trabajo compara la descomposición de la hojarasca de aliso y sauce en dos sistemas (lenítico y lótico) situados en dos localidades (Caxarias y Alpiarça). Se utilizaron bolsas para hojarasca para comparar la descomposición entre los diferentes tratamientos. Se determinaron las pérdidas de peso seco, contenido en $N$ y $P$ en el detritus vegetal, perfiles fisiológicos de la comunidad microbiana, la colonización microbiana y de macroinvertebrados a los 2, 4, 8, 16, 32 y 64 días del experimento. Las tasas de descomposición variaron de intermedias a rápidas para el aliso $\left(0.006\right.$ día ${ }^{-1}$

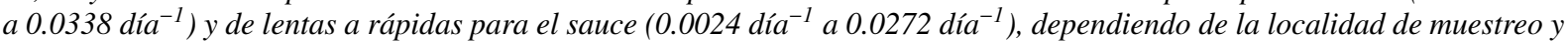
del tipo de sistema. Los efectos combinados sistema $\times$ tiempo resultaron significativos para los heterótrofos totales $(\mathrm{p}<0.05)$, hongos filamentosos $(\mathrm{p}<0.05)$ y levaduras $(\mathrm{p}<0.001)$. El análisis del desarrollo medio del color $(A W C D)$, la riqueza $(R)$ y el índice de Shannon-Wiener $\left(H^{\prime}\right)$ basados en la oxidación de las fuentes de nitrógeno y carbono por parte de la comunidad microbiana, mostraron diferencias entre los dos sistemas, lótico y lenítico y entre las localidades de muestreo. Estas diferencias se pusieron también de manifiesto en el análisis de componentes principales (PCA). Además, las comunidades de 
macroinvertebrados claramente diferenciaron los sistemas leníticos de los lóticos. Se observó que en los sistemas leníticos los organismos pertenecientes a Plecoptera, Ephemeroptera y Trichoptera estaban ausentes.

Palabras clave: Hojarasca, bosques pantanosos, descomposición, lótico, lenítico, microorganismos, macroinvertebrados.

\section{INTRODUCTION}

Decomposition is a key process in ecosystems, especially the ones that depend on allochtonous organic matter to function. Because it is a complex process involving both abiotic and biotic factors, this kind of study is frequently used to assess the functional and structural integrity of ecosystems (Pascoal et al., 2003; Lecerf et al., 2006). Along with environmental factors, the dynamics of decay is influenced by intrinsic litter parameters such as the chemical composition of detritus, microbial, and macroinvertebrate colonization (Ostrofsky, 1997; Suberkropp, 1998; Graça, 2001).

Forested wetlands are defined as naturally inundated or saturated areas that support a significant component of woody vegetation adapted to poorly aerated and/or saturated soil (Lugo, 1990). They are interfaces between terrestrial and freshwater systems and fulfill several important roles in global hydrology (Cronk \& Fennessy, 2001), biogeochemical cycling, the filtration of nutrients from agricultural pollution (Naiman \& Décamps, 1997; Messina \& Conner, 1998; Rheinhardt et al., 1998), acting as carbon sinks (Lugo et al., 1990), regulating and maintaining landscape biodiversity (Dynesius \& Nilsson, 1994), and promoting regional ecological diversity (Naiman \& Décamps, 1997). In addition, forested wetlands are among the most fragile of all ecosystems (Nilsson \& Grelsson, 1995), and in spite of their differences between truly terrestrial or aquatic systems, they are highly dependent on both. Compared to other systems, wetlands sensu lato are perhaps the natural systems that have most suffered alterations as a result of the creation of agricultural landscapes (GallegoFernández et al., 1999). In Spain, 60 \% of wetlands had disappeared during the second half of the twentieth century (Hughes, 1995). Despite their ecological role and endangered status there is no accurate estimate of the total area covered by forested wetlands in the Iberian Peninsula, and namely in Portugal (Brinson \& Malvárez, 2002). The existing research about ecosystem functioning is mostly limited to strictly riverine forests (e.g. Pozo, 1993; Mollá et al., 1994; López et al.; 1997; Sampaio et al., 2001; Molinero \& Pozo, 2003). Recent interest focused in swamp forests (standing water systems) has been demonstrated through some studies on their flora (Amigo et $a l ., 2004)$ and vegetation ecology (RodríguezGonzález et al., 2004), but their ecological functioning remains poorly understood.

Hydroperiod is the most critical environmental factor in a wetland's energy signature (Lugo et al., 1990). Flooded conditions are thought to promote decomposition (Lockaby \& Wallbridge, 1998), but, on the other hand, aerobic/moist conditions promote decomposition to the greatest extent followed by dry and anaerobic conditions in that order (Cronk \& Fennesy, 2001). The first case would correspond to riverine forests where the release of nutrients from the decomposition of leaf litter is usually rapid enough, resulting in little or no accumulation from year to year (Brinson, 1990). On the other hand, the decomposition of litter tends to slow down in an anaerobic environment (Wiegers, 1990).

The main goal of this study was to assess how the decomposition of leaves of alder and willow is affected by grove type (Alpiarça and Caxarias) in two aquatic forest inter-related biotopes, 


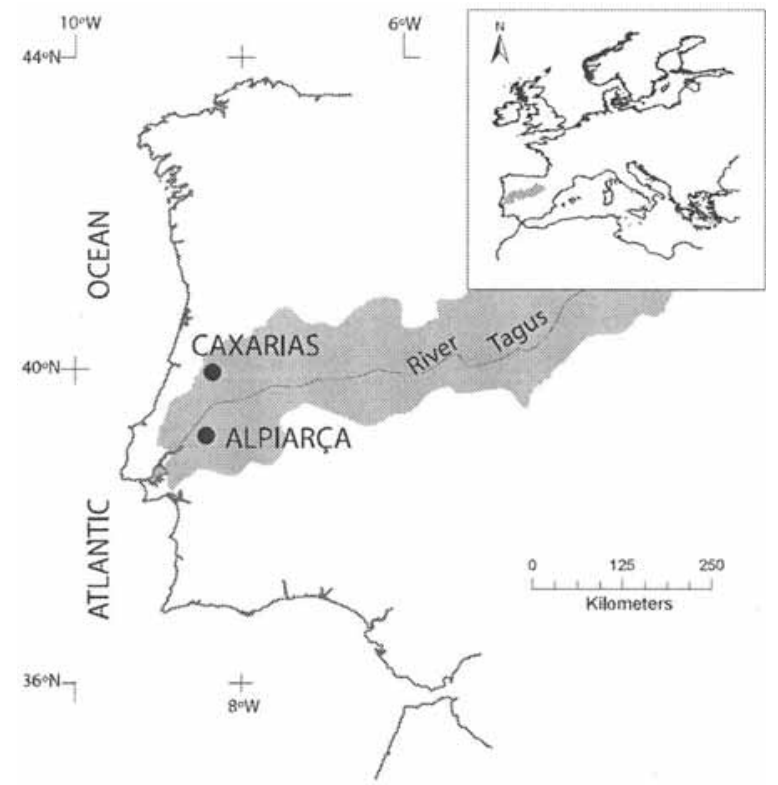

Figure 1. Location of Alpiarça and Caxarias sampling areas. Localización de las áreas de muestreo de Alpiarça y Caxarias.

namely lotic and lentic, considering chemical changes, microbial densities, and function, and the effect of macroinvertebrates.

\section{FIELD SITES}

Alpiarça and Caxarias are two forested wetland systems located in the south west of the Iberian
Peninsula in Portugal. Both systems have developed above quaternary deposits in inland depressions of the Tagus River hydrographic basin (Fig. 1). The average altitude is $17 \mathrm{~m}$ in Alpiarça and $119 \mathrm{~m}$ in Caxarias. The mean annual precipitation and mean annual temperature are $715 \mathrm{~mm}$, $15.9^{\circ} \mathrm{C}$, and $795 \mathrm{~mm}, 15.7^{\circ} \mathrm{C}$ respectively. Tree cover is dominated by willow (Salix atrocinerea) in Alpiarça and alder (Alnus glutinosa) in Caxarias. These species grow under waterlogged conditions from October until June. Superficial water displays a complete flow gradient from fast running to standing conditions and we selected one lotic and one lentic (Fig. 2) sampling sites in both the Alpiarça and Caxarias systems to carry out our experiments. The main physicochemical parameters of superficial waters of the four sampling sites are showed in Table 1.

\section{MATERIAL AND METHODS}

\section{Leaf litterbags and sample processing}

Litter decay experiments took place from $25^{\text {th }}$ January to $4^{\text {th }}$ April 2006, using senescent leaves of A. glutinosa, and S. atrocinerea picked from the trees in early November 2005 in Northeast Portugal and air dried at $40^{\circ} \mathrm{C}$ for 48 hours. This dehydration step was aimed at eliminating phyl-

Table 1. Variation of the physico-chemical water parameters during the experiments (January-April) in the four sampling sites. Variación de los parámetros físico-químicos del agua durante la realización de los experimentos (Enero-Abril) en los cuatro puntos de muestreo.

\begin{tabular}{|c|c|c|c|c|}
\hline \multirow[b]{2}{*}{ Sampling site } & \multicolumn{2}{|c|}{ Alpiarça } & \multicolumn{2}{|c|}{ Caxarias } \\
\hline & A-Lo & A-Le & C-Lo & C-Le \\
\hline $\begin{array}{l}\text { Latitude } \\
\end{array}$ & $39^{\circ} 13^{\prime} 59^{\prime \prime}$ & $39^{\circ} 13^{\prime} 43^{\prime \prime}$ & $39^{\circ} 42^{\prime} 40^{\prime \prime}$ & $39^{\circ} 43^{\prime} 08^{\prime \prime}$ \\
\hline Longitude & $08^{\circ} 32^{\prime} 29^{\prime \prime}$ & $08^{\circ} 34^{\prime} 32^{\prime \prime}$ & $08^{\circ} 31^{\prime} 19^{\prime \prime}$ & $08^{\circ} 30^{\prime} 56^{\prime \prime}$ \\
\hline Superficial water & running & standing & running & standing \\
\hline Level above ground $(\mathrm{cm})$ & $20.0-40.0$ & $7.0-14.0$ & $25.0-31.0$ & $10.0-12.0$ \\
\hline Dissolved $\mathrm{O}_{2}(\mathrm{mg} / \mathrm{l})$ & $5.5-9.3$ & $3.7-5.3$ & $6.3-8.7$ & $4.0-5.7$ \\
\hline Redox Potential (mV) & $72.0-110.0$ & $136.0-173.0$ & $58.0-97.0$ & $79.0-106.0$ \\
\hline Conductivity $(\mu \mathrm{S} / \mathrm{cm})$ & $267.0-335.0$ & $165.0-231.0$ & $160.0-185.0$ & $158.0-199.0$ \\
\hline $\mathrm{pH}$ & 7.2 & $6.3-6.5$ & 7.4 & 6.9 \\
\hline Temperature $\left({ }^{\circ} \mathrm{C}\right)$ & $8.5-15.0$ & $10.9-15.6$ & $11.9-15.9$ & 7.9-15.2 \\
\hline $\mathrm{NO}_{3}^{-}(\mathrm{mg} / \mathrm{l})$ & $16.0-35.0$ & $5.3-8.2$ & $3.2-5.5$ & $0.3-1.6$ \\
\hline $\mathrm{NH}_{4}^{+}(\mathrm{mg} / \mathrm{l})$ & $0.05-0.06$ & 0.05 & $0.05-0.07$ & $0.05-0.13$ \\
\hline $\mathrm{NO}_{2}^{-}(\mathrm{mg} / \mathrm{l})$ & 0.11 & 0.003 & 0.007 & 0.008 \\
\hline $\mathrm{PO}_{4}^{3-}(\mathrm{mg} / \mathrm{l})$ & 0.22 & 0.10 & 0.04 & 0.40 \\
\hline
\end{tabular}



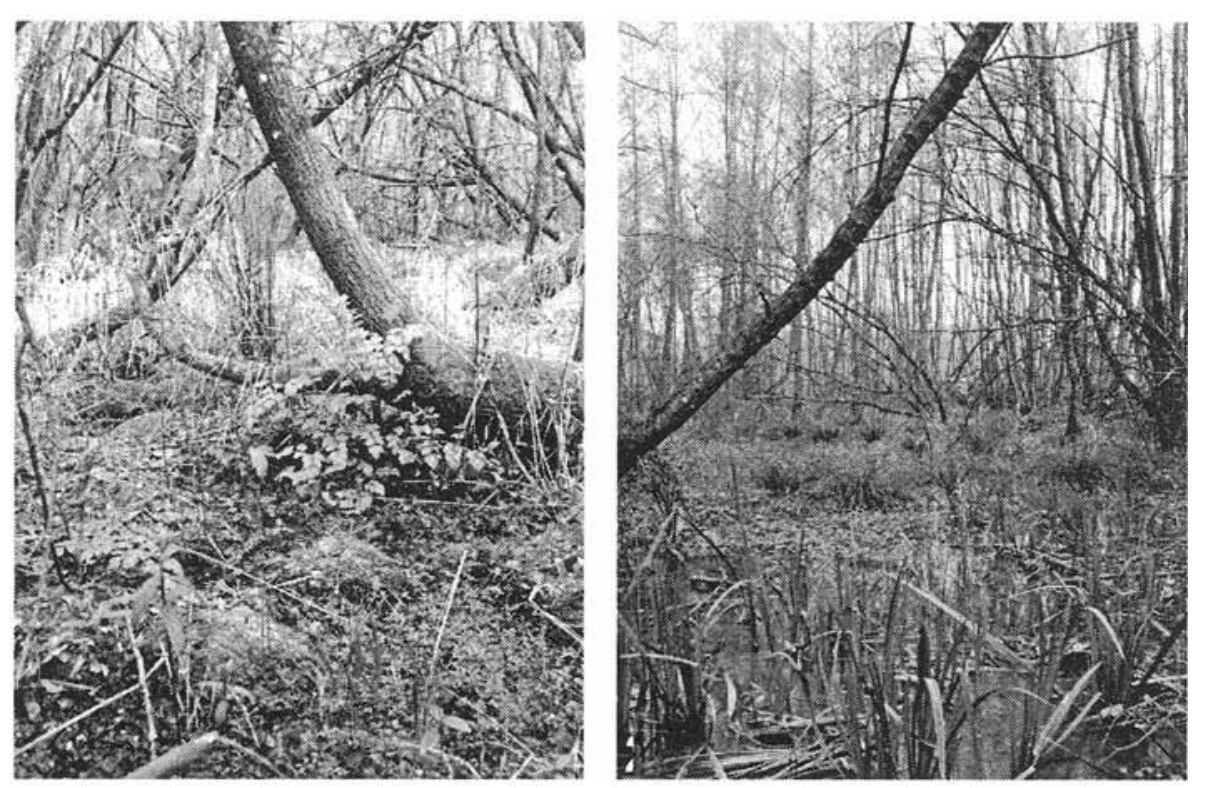

Figure 2. Interior appearance of lentic area in 1: Alpiarça (Willow dominance) and 2: Caxarias (Alder dominance). Aspecto del interior del área pantanosa de sauceda en Alpiarça (1) y de aliseda en Caxarias (2).

loplane microorganisms, facilitating the storage of the leaves. Before the decay experiment 5$\mathrm{mm}$ mesh litterbags were tagged and each one took $4 \mathrm{~g}$ of dry leaves, which were re-hydrated before they were enclosed in the bags. Both in Alpiarça and Caxarias, the closed bags were attached to nylon ropes or left free, depending on if the experiment would take place in the lotic or in the lentic system, respectively. After $2,4,8,16,32$, and 64 days of immersion each litterbag was enclosed in a plastic bag and transported to the laboratory in a cool box. For each sampling period and study type, six bags of each leaf species were collected.

At the laboratory, the leaves in three bags were washed with tap water and separated from the macroinvertebrates. All organisms collected were placed into a vial with $70 \%$ ethanol and preserved until its taxonomic identification. Invertebrates were identified to genus level under a stereoscope, with the exception of Hydracarina (order), Diptera (family or sub-family for Chironomidae) and Oligochaeta (family). All organisms were counted.

The leaf content was oven dried at $104^{\circ} \mathrm{C}$ (48 hours), to obtain residual dry mass (RDM), grounded and used for determination of total organic carbon (TOC), total nitrogen, and total phosphorus. We determined total nitrogen by the Kjeldahl technique, total phosphorus by the molybdovanate method (Mills \& Jones, 1996). TOC was determined after a high temperature combustion $\left(1100^{\circ} \mathrm{C}\right)$, and detection of the resulting carbon dioxide was achieved by a non-dispersive infrared (NDIR) detector. These parameters were expressed as percentage of dry weight.

\section{Litter decomposition rates}

The obtained RDM values were used to determine the decomposition rates, using the Petersen and Cummins's equation: $k=-(1 / t) \cdot \ln \left(W_{t} / W_{0}\right)$, where $W_{t}$ is the dry weight after time $t$, and $W_{0}$ is the initial dry weight. The statistical significance of the decomposition rates was determined by the t-test (Zar, 1984) using the GraphPad Prism 4, version 4.03.

\section{Microbiological Analyses}

To characterise the dynamics of the litter microorganisms, several approaches are possible. 
These include the quantification of cultivable microbes on selective media and community level physiological profiling (CLPP).

\subsection{Colony-forming units (CFU) dynamics}

For the quantification of microorganisms that colonised the leaves, two litterbags were used, as already described by Sampaio et al. (2001). Because the suspended litter was used for inoculating both Petri dishes and Biolog plates, the medium of suspension must be free of any carbon and nitrogen sources, and the $0.1 \%$ peptone water was substituted by a sterilised $0.85 \% \mathrm{NaCl}$ solution. The resulting suspensions were inoculated into R2A, Wort Agar and Rose Bengal Agar media (Difco, U.S.A.) and the results expressed in CFUs per $g$ of foliar dry mass.

\subsection{Community level physiological profiling $(C L P P)$}

The microbial suspensions were also used to inoculate the Biolog EcoPlates (Biolog, Inc.). Each 96-well plate contains 31 sole carbon sources, useful for community analysis, repeated 3 times and 3 blank-wells without any carbon source. The content of the litterbags was suspended in a sterilised solution $0.85 \% \mathrm{NaCl}$, shaken for $30 \mathrm{~min}$., and sonicated for $3 \mathrm{~min}$. Before incubation in microplates we performed a 1:10 dilution and aliquots of $145 \mu \mathrm{l}$ were inoculated in each well. The plates were incubated at $20^{\circ} \mathrm{C}$, and the colour development in each well was recorded as optical density (OD) at $590 \mathrm{~nm}$ with a plate reader Labsystems-Multiskan, every 12 hours along four days. The raw data were used to determine the average well-colour development (AWCD) in each microplate (Gomez et al., 2006). The number of oxidized carbon substrates, expressed as richness $(\mathrm{R})$, and the Shannon-Wiener index $\left(\mathrm{H}^{\prime}\right)$ were calculated using an OD of 0.25 as threshold for positive response (Garland, 1997).

\section{Statistical Analysis}

Colony forming units per $\mathrm{g}$ of dry weight and the AWCD and $\mathrm{H}^{\prime}$ data obtained from the analyses
Table 2. Initial chemical composition of the three main components in litters (mean; $n=6$ ). Values are represented as a percentage of residual dry weight. Standard deviation $<7 \%$, in all parameters. Composición química inicial de los tres principales componentes en la hojarasca (media; $\mathrm{n}=6$ ). Valores representados como porcentaje del peso seco residual. Desviación estándar $<7 \%$ en todos los parámetros.

\begin{tabular}{lrr}
\hline Parameters (\% dry weight) & Alder & Willow \\
\hline Total Nitrogen & 2.30 & 1.50 \\
Total Phosphorus & 0.08 & 0.13 \\
Total Organic Carbon (TOC) & 55.60 & 47.80 \\
\hline
\end{tabular}

of the CLPP, were log-transformed and analysed by factorial variance (ANOVA) to detect differences among treatments (site/biotope/litter/time of decay), using the software STATISTICA version 7.0. Furthermore, we performed a principal component analysis (PCA) to elucidate the pattern of variation of CLPP of 31 different substrates, using the data corresponding to $48 \mathrm{~h}$ of incubation, and, after, we standardized the AWCD in each microplate to minimise inoculum density effects (Garland 1997). The PCA analysis was performed with PRIMER 5, version 5.2.2 (Clarke \& Gorley, 2001).

A Non Metric Multidimensional Scaling (NMDS) analysis, performed with STATISTICA v.7.0, tested if it was possible to detect distinct macroinvertebrate assemblages between the leaves of alder and willow, as well as between the two types of aquatic systems. This analysis considers

Table 3. Decay rates, determined by a negative exponential model of residual dry weights, obtained in Alpiarça and Caxarias and the respective determination coefficients $\left(\mathrm{R}^{2}\right)$. Three replicates were done for each sampling period. Tasas de decomposición determinadas por el modelo exponencial negativo de los pesos secos residuales, obtenidas en Alpiarça y en Caxarias y respectivos coeficientes de determinación $\left(R^{2}\right)$. Para cada período de muestreo fueron efectuadas 3 réplicas.

\begin{tabular}{lcccc}
\hline Site & Biotope & Litter & $\boldsymbol{- k}\left(\mathbf{d a y}^{\mathbf{- 1}}\right)$ & $\mathbf{R}^{\mathbf{2}}$ \\
\hline \multirow{3}{*}{ Alpiarça } & Lotic & Alder & 0.0117 & 0.87 \\
(willow-grove) & \multirow{2}{*}{ Lentic } & Willow & 0.0154 & 0.87 \\
& & Alder & 0.0497 & 0.93 \\
& & Willow & 0.0272 & 0.81 \\
& \multirow{2}{*}{ Lotic } & Alder & 0.0338 & 0.91 \\
& & Willow & 0.0170 & 0.76 \\
Caxarias & \multirow{2}{*}{ Lentic } & Alder & 0.0060 & 0.64 \\
(alder-grove) & & Willow & 0.0024 & 0.18 \\
& & & &
\end{tabular}


the rank order of distances between objects, which are obtained from a previous classification of the samples using the Euclidean distance.

\section{RESULTS}

\section{Decomposition Rates}

The chemical composition of the initial litter is shown in Table 2. Alder leaves presented higher initial nitrogen and TOC contents than willow. Nevertheless, willow had more phosphorus than alder. In both biotopes, nitrogen increased throughout decay, wherever the sites considered. The same trend was followed by phosphorus in streams, but not in lentic systems, where phosphorus decreased along litter decomposition.

Alder litter decay rates varied from $0.006 \mathrm{day}^{-1}$ to $0.049 \mathrm{day}^{-1}$, while willow rates ranged from $0.002 \mathrm{day}^{-1}$ to $0.027 \mathrm{day}^{-1}$, indicating that alder leaves degraded faster than willow leaves (Table 3). Regarding the site where the experiments took place, Caxarias exhibited higher decomposition rates than Alpiarça for litter degrading in the streams, while for lentic systems, the latter site presented the highest decay values.

The t-test analyses revealed (Table 4) significant differences between lotic and lentic habitats for alder, both in Alpiarça $(F=17.45$, $p=0.0029)$ and in Caxarias $(\mathrm{F}=22.20$, $p=0.0015)$. Lotic and lentic willow decay rates were significantly different in Caxarias, $(\mathrm{F}=10.18, p=0.0125)$ but not in Alpiarça.

\section{Litter microbial colonisation}

Total heterotroph numbers per foliar dry weight (Fig. 3) varied significantly between sites $(\mathrm{F}=10.709, p=0.00122)$ and throughout decomposition $(\mathrm{F}=6.02, \quad p=0.000029)$. The variance of combined treatments was significantly different for site $\times$ time $(p<0.01)$ and biotope $\times$ time $(p<0.05)$. Molds per dry weight (data not shown) significantly changed along time $(p<0.0001)$, site $\times$ time $(p<0.05)$, biotope $\times$ time $(p<0.05)$, and litter $\times$ time $(p<0.01)$. Yeast counts were different between Caxarias

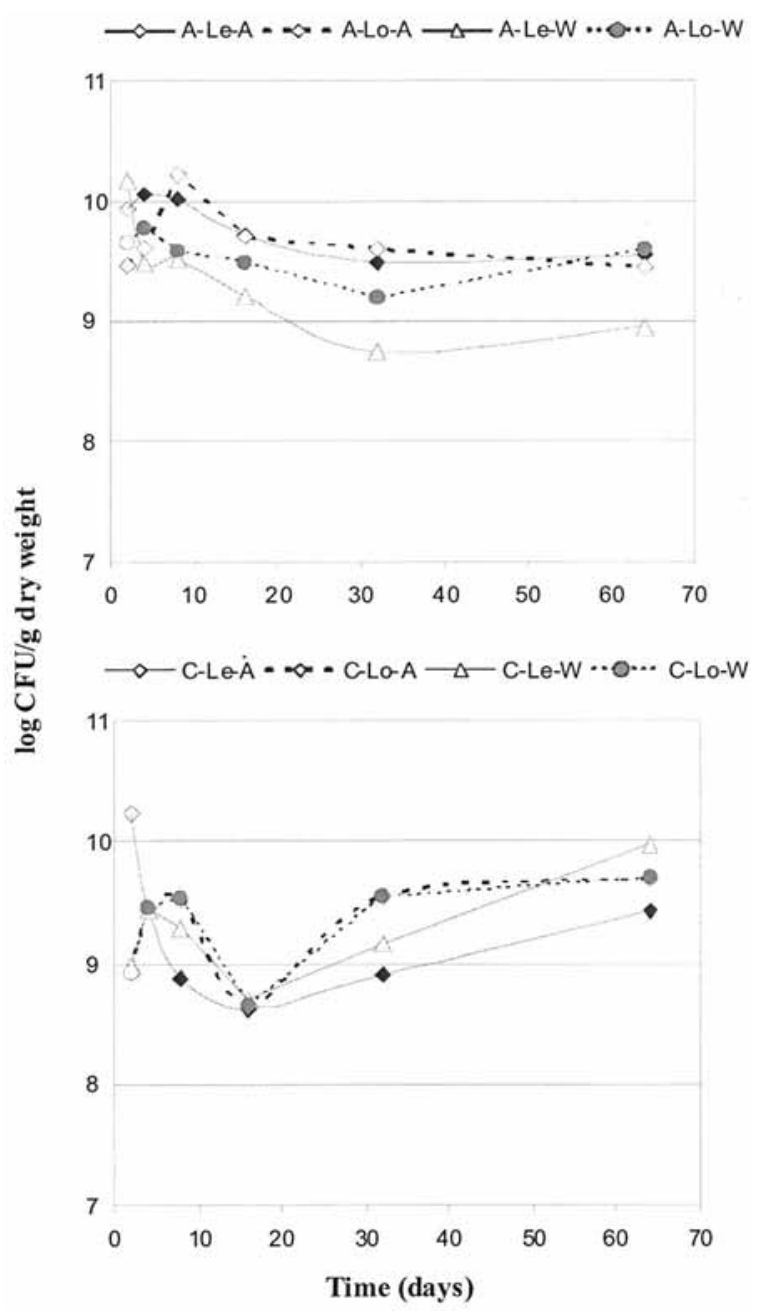

Figure 3. Total abundance of heterotrophic (R2A medium) colony forming units (CFU) per foliar dry weight $(\mathrm{g})$ along decomposition ( $\mathrm{n}=$ median of 6 independent samples). A: Alpiarça; C: Caxarias; Lo: lotic; Le: lentic; Al: alder; W: willow. Abundancia total de heterótrofos (medio R2A) medido como unidades formadoras de colonias (CFU) sobre el peso seco de hojas $(\mathrm{g})$ durante la descomposición ( $n=$ mediana de 6 muestras independientes). A: Alpiarça; C: Caxarias; Lo: lótico; Le: lenítico; Al: aliso; W: sauce.

and Alpiarça $(p<0.01)$, as well as during decay $(p<0.01)$. Also, yeast densities were distinct when we combined time $\times$ site $(p<0.0001)$, time $\times$ biotope $(p<0.001)$, and time $\times$ litter $(p<0.05)$. Contrary to the other microbial groups, the interaction of the effects site $\times$ litter $\times$ time on yeasts was significant $(p<0.001)$, as well as for all the combined effects (site $\times$ biotope $\times$ litter $\times$ time). 
Table 4. Significant differences between decay rates (t-student test). Ns: not significant, ${ }^{*}(p<0.05)^{* *}(p<0.01)$ and ${ }^{* * *}$ ( $p$ < 0.0001). A: Alpiarça; C: Caxarias; Lo: lotic; Le: lentic; Al: alder; W: willow. Diferencias significativas entre las tasas de descomposición (test t de student). Ns: no significativo, ${ }^{*}(\mathrm{p}<0.05)^{* *}(\mathrm{p}<0.01)$ and $^{* * *}(\mathrm{p}<0.0001)$. A: Alpiarça; C: Caxarias; Lo: lotico; Le: lenítico; Al: aliso; W: sauce.

\begin{tabular}{llllllllll}
\hline & A-Lo-Al & & & & & & \\
\hline A-Lo-Al & & A-Lo-W & & & & & \\
A-Lo-W & Ns & & A-Le-Al & & & & \\
A-Le-Al & $* *$ & $*$ & & A-Le-W & & & \\
A-Le-W & Ns & Ns & $* * *$ & & C-Lo-Al & & & \\
C-Lo-Al & $*$ & Ns & Ns & Ns & & C-Lo-W & & \\
C-Lo-W & Ns & Ns & $*$ & Ns & Ns & & C-Le-Al & \\
C-Le-Al & $*$ & Ns & $* * *$ & $* *$ & $* *$ & $*$ & & C-Le-W \\
C-Le-W & Ns & $*$ & $* * *$ & $* * *$ & $* * *$ & $*$ & Ns & \\
\hline
\end{tabular}

In general, AWCD presented higher values in streams than in lentic systems, no matter the litter type considered (Table 5). Also, both the average of the Shannon-Wiener index $\left(\mathrm{H}^{\prime}\right)$ and richness were higher in streams. We found significant variations $(p<0.0001)$ in AWCD between the lotic and the lentic systems and the litter type. The $\mathrm{H}^{\prime}$ was also distinct between the two biotopes $(p<0.0001)$ and litter species $(p<0.05)$. The effect of all treatments (site $\times$ biotope $\times$ litter) was not significant for $\mathrm{H}^{\prime}$, but it was highly significant for AWCD $(p<0.0001)$.

The first and the second principal components (PC1 and PC2) explained $57.3 \%$ of the total data variance (Figure 4). A temporal gradient could easily observed from the plot, where substrates such as glycogen, D-cellobiose, $\beta$-methyl-Dglucoside, D-mannitol, N-acetyl-D-glucosamine, 4-hydroxy benzoic, L-arginine, L-aspargine and

Table 5. Average well colour development (AWCD), richness $(\mathrm{S})$, and Shannon-Wiener index $\left(\mathrm{H}^{\prime}\right)$ values based on substrate used in Biolog Ecoplates. Desarrollo medio del color (AWCD), riqueza $(S)$ e índice de Shannon-Wiener $\left(H^{\prime}\right)$ calculado en base a la utilización de sustrato en Biolog Ecoplates.

\begin{tabular}{llccc}
\hline Site & Sample & AWCD & S & $\mathbf{H}^{\prime}$ \\
\hline \multirow{3}{*}{ Alpiarça } & Lotic alder & 0.824 & 25 & 3.18 \\
& Lotic willow & 0.777 & 23 & 3.14 \\
& Lentic alder & 0.542 & 20 & 3.06 \\
& Lentic willow & 0.623 & 20 & 2.98 \\
& Lotic alder & 0.797 & 24 & 3.17 \\
Caxarias & Lotic willow & 0.798 & 24 & 3.17 \\
& Lentic alder & 0.565 & 21 & 3.08 \\
& Lentic willow & 0.726 & 23 & 3.10 \\
\hline
\end{tabular}

putrescine were correlated with $\mathrm{PC} 1$ axis, while $\alpha$-D-lactose, i-erythritol, 2-hydroxy benzoic, Dgalacturonic, itaconic and $\alpha$-ketobutyric acids, L-phenylalanine, L-serine, and phenylethylamine were correlated with $\mathrm{PC} 2$ axis. For all the treatments, the samples belonging to lentic and lotic systems seemed more clustered with each other, than those of the other situations (site and litter).

\section{Macroinvertebrates}

Table 6 represents in detail the differences in abundance for the dominant taxa. We can observe distinct patterns for the fauna of both locations (Alpiarça and Caxarias) as well as between lotic or lentic habitats. In bags placed in the lentic systems we recorded a lower macroinvertebrate density, and absence of organisms adapted to currents like Simullidae, Plecoptera, Ephemeroptera, and Trichoptera. These systems had a general lower diversity, which is almost restricted to Chironomidae, Asellidae, and Oligochaeta. The orders Ephemeroptera, Plecoptera, and Trichoptera (EPT) appeared in the litterbags placed in river habitats, after day 32 , and were consistently more abundant on day 64. Ephemerella, Isoperla, and Hydropsyche spp. were the most representative groups. Another difference between both aquatic systems was an important population of Crustacea (Procambarus clarkii) in the lentic systems (almost absent in streams) The NMDS diagram (Fig. 5) shows the differences between the macroinverte- 

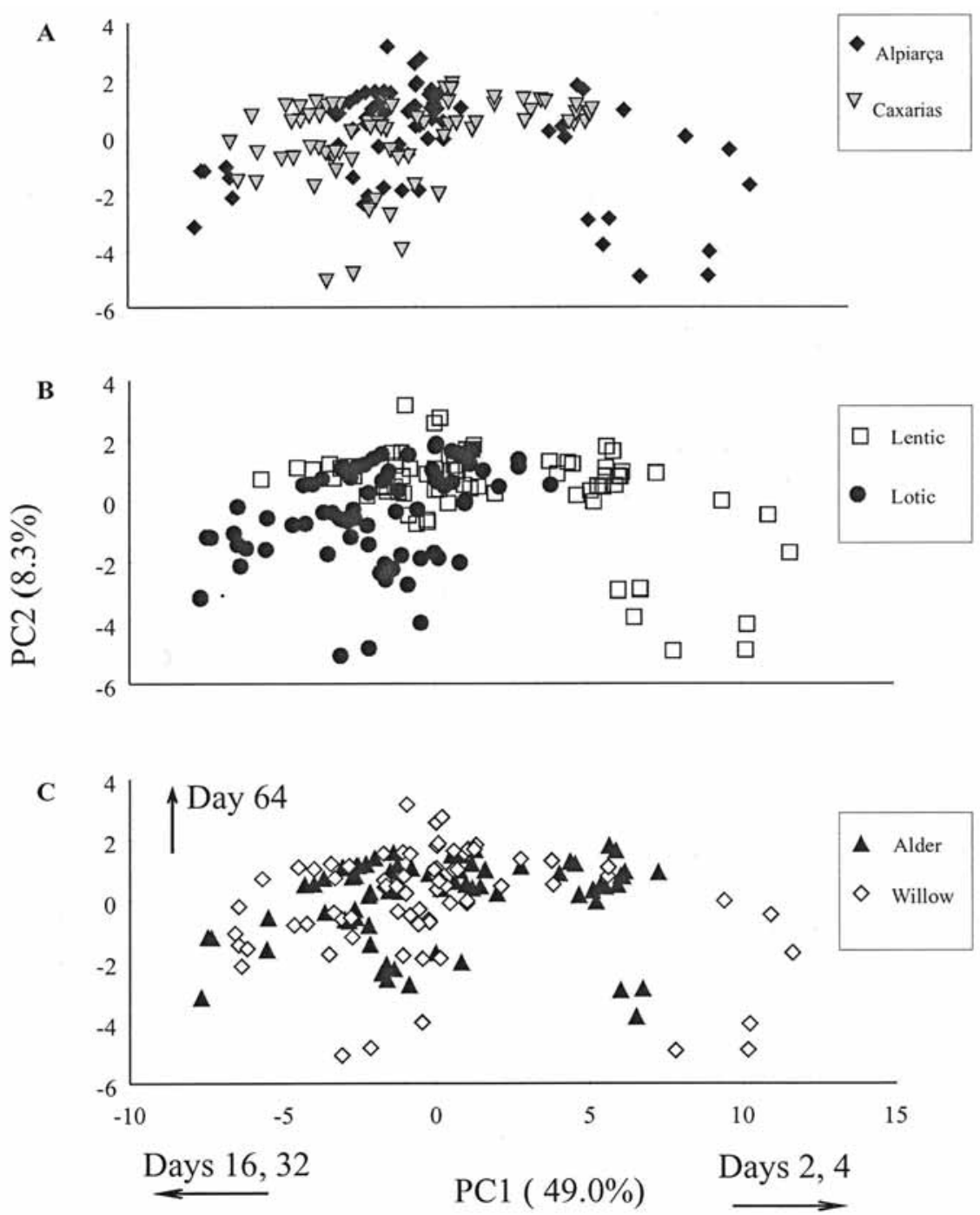

Figure 4. Two-dimensional PCA ordination (A, B, and C) of log-transformed community level physiological profiling (CLPP) data, based on the factor site (A), biotope (B), and litter type (C). PC1 and PC2 account for $57.3 \%$ of the total variance. Ordenación PCA bidimensional (A, B y C) de los parámetros químicos log-transformados, basada en el factor local (A), biotopo (B) y tipo de hojarasca (C). PC1 y PC2 suman un total de $57.3 \%$ de la variación total.

brate assemblages colonizing both leaf species, the two locations and, inside each site, the comparison between the lotic and the lentic systems or the incubation periods. The similarity among the samples is more obvious for the first days of colonisation (the samples are notoriously clumped in the diagram), and on the contrary, the last days of incubation exhibit a larger dispersion along the two first axes of the ordination indicating specific taxa.

\section{DISCUSSION}

According to Petersen \& Cummins (1974) the decay rates obtained in this study, can be classified as rapid $\left(0.01 \mathrm{day}^{-1}>k>0.005 \mathrm{day}^{-1}\right)$ for almost all treatments, intermediate for lentic alnus in Caxarias, and slow for lentic willow in Caxarias. The breakdown rates of both litters were higher in lotic systems, with the exception of Alpiarça. Gessner \& Chauvet (1994), 
Table 6. Comparison of the dominant taxa (total number per sample) between biotope (lotic and lentic) and between leaf species (alder and willow). Comparación de los taxa dominantes (número total por muestra) entre biotopos (lótico y lénítico) y entre la especie de hoja (aliso y sauce).

\begin{tabular}{|c|c|c|c|c|c|c|c|c|}
\hline \multirow[b]{3}{*}{ Taxa } & \multicolumn{4}{|c|}{ Alpiarça } & \multicolumn{4}{|c|}{ Caxarias } \\
\hline & \multicolumn{2}{|c|}{ Lotic } & \multicolumn{2}{|c|}{ Lentic } & \multicolumn{2}{|c|}{ Lotic } & \multicolumn{2}{|c|}{ Lentic } \\
\hline & Alder & Willow & Alder & Willow & Alder & Willow & Alder & Willow \\
\hline Chironomidae & 88 & 60 & 3 & 0 & 34 & 9 & 44 & 33 \\
\hline Asellidae & 0 & 1 & 2 & 0 & 0 & 0 & 18 & 18 \\
\hline Gastropoda & 1 & 0 & 0 & 0 & 43 & 1 & 41 & 0 \\
\hline Oligochaeta & 12 & 19 & 0 & 0 & 0 & 0 & 52 & 37 \\
\hline Simullidae & 31 & 26 & 0 & 0 & 2 & 6 & 0 & 0 \\
\hline Plecoptera & 0 & 0 & 0 & 0 & 14 & 19 & 0 & 0 \\
\hline Ephemeroptera & 12 & 6 & 0 & 0 & 18 & 7 & 0 & 0 \\
\hline Trichoptera & 0 & 0 & 0 & 0 & 10 & 10 & 0 & 0 \\
\hline
\end{tabular}

Pozo et al. (1998) and Sampaio et al. (2001), obtain similar rates for alder leaf litter. From the analysis of decomposition rates we can say that in some situations the biotope type makes the difference, in other the site of sampling and the litter species seems determinant, and, in some situations, such as Caxarias lotic Alnus (C-Lo-Al) and Alpiarça lentic Willow (A-Le-W), no differences were observed.

Leaf litter decomposition is a complex process that involves intrinsic and extrinsic factors. Among the first ones is the initial litter chemical composition, especially nutrient and fibre content (Melillo et al., 1982; Taylor et al., 1989). The nutrient contents ( $\mathrm{N}$ and $\mathrm{P}$ ) of both alder and willow leaves obtained in this work are comparable to those obtained in other studies (Canhoto \& Graça, 1996; Maie et al., 2003; Richardson et al., 2004). Environmental (e.g. temperature, conductivity, $\mathrm{pH}$ ) and biotic (microbial and invertebrate colonisation) parameters also influence decay rates.

Microbial densities varied significantly with time of decomposition (total heterotrophs, molds, and yeasts), and between sites (heterotrophic bacteria and yeasts). The densities of total heterotrophs achieved were higher in comparison to other studies (Sampaio et al., 2001; Gonçalves et al., 2006), whatever the situation considered. Nevertheless, we ought to notice that these authors studied leaf litter decay in different environments, and only in streams. The combined effects biotope $\mathrm{x}$ time showed differences in all the microbial groups considered. Particularly, yeasts seem to be more sensitive to the combined effects of site/biotope/litter and time, which is not a surprise, since these organisms have a high specialization in their habitats (Phaff \& Starmer, 1980). Together with microbial group density and structure, the study of function may reveal differences among the treatments (Insan \& Goberna, 2004; Gomez et al., 2006). In fact, the analysis of the AWCD values indicated that the microbial activity were different between the two aquatic systems, between leaf types, and between locations. The distinct microbial patterns in

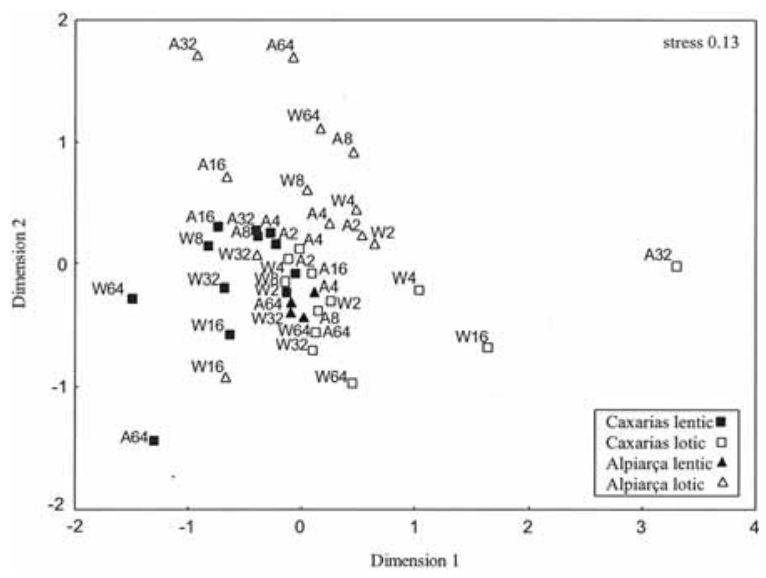

Figure 5. NMDS analyses (stress $=0.13$ ) of invertebrate colonization along the 64 days of the experiment. The labels indicate the leaf species (A, alder; W, willow) and the sampling day number. Análisis NMDS (stress $=0.13$ ) de la colonización de invertebrados durante los 64 días del experimento. Las etiquetas representan la especie de hoja (A, aliso; W, sauce) y el número del día de muestreo. 
using $\mathrm{C}$ and $\mathrm{N}$ sources may be related to different microbial community structures, possibly due to biotope or site specificities such as oxygen concentration, nitrate and phosphate concentrations, and even vegetation dominance (Gulis \& Suberkropp, 2003; Hahn, 2003; Gulis et al., 2006). Additionally, different chemical composition and anatomic traits between alder and willow, can explain the variation in microbial colonisation (Webster \& Benfield, 1986). Nevertheless, differences in CLPP profiles must be interpreted with caution since the dominance of certain microbial species can give misleading results (Insan \& Goberna, 2004). In terms of substrate diversity and richness $\left(\mathrm{H}^{\prime}\right.$ and $\left.\mathrm{S}\right)$, lotic systems presented higher values than lentic ones in both litter types.

The obtained physico-chemical parameters in the four site types, namely oxygen, temperature, nutrient concentration, and potential redox values can elucidate the significant variations in decomposition rates among them (López et al., 2001; Pascoal \& Cássio, 2004). Although the maximum temperature values in all four sites (Alpiarça and Caxarias, lotic and lentic) were very similar, there are differences of $3^{\circ} \mathrm{C}$ in the minimum temperatures between lotic and lentic biotopes. Also, nitrate concentration, higher in Alpiarça biotopes, may explain the higher microbial counts, which in turn can influence decay rates directly, by promoting the growth of microorganisms, or indirectly by increasing the palatability of leaf litter to detritivores.

A high number of works had showed that slow leaf processing depends on the quality of litter species, and that the density or biomass of shredders is related to the nutrient content (we may exemplify with Kaushik \& Hynes, 1971; Melillo et al. 1982; Cortes et al. 1994, Sampaio et al., 2004; Gulis et al. 2006). These studies focused on lotic systems, and the literature concerning comparisons between running waters and adjacent wetlands is very scarce. Our results revealed a lack of a specific pattern when compared with the ones mentioned in most of the literature (Lockaby \& Wallbridge, 1998). The expected lower rates in lentic biotopes, which occurred in Caxarias site in both litters, contradicted the highest $k$ values observed in the Alpiarça lentic habitat.
It is recognised that shredder density influences decay rates (e.g. Benfield \& Webster, 1985; Ferreira et al., 2006). However, the Caxarias lentic system, which had an important population of Isopoda (Asellus sp.), did not show higher decay rates when compared to the same system in Alpiarça. This trend was not followed in the Caxarias lotic system, where the abundance of EPT macroinvertebrates was in fact traduced into higher breakdown rates when compared with the lotic Alpiarça system. The highest breakdown rates obtained in the lentic Alpiarça system may had be influenced by the presence of Procambarus clarkii. This alien crayfish is a polytrophic and opportunistic species, consuming detritus colonised by microorganisms, benthic and planktonic invertebrates, and succulent plant material (Huner \& Lindqvist, 1995; Gutiérrez et al., 1998). Moreover, P. clarkii tolerates low oxygen concentrations, a wide range of water salinity, and seasonal fluctuations in water levels (Barbaresi \& Gherardi, 2000). Concerning the main comparisons between lentic versus lotic assemblages, we can highlight the very low diversity of macroinvertebrates colonizing litters in the lentic sites. In addition, in this habitat, EPT group and Simulliidae are absent, but Asellus are abundant.

The overall results show differences between the sites and the biotopes considered. Decomposition rates, microbial quantification, and CLPP microbial abilities seem to respond, in a greater or lesser extent, roughly to different habitats (lotic versus lentic) and to site variations. The macroinvertebrate colonization firstly distinguished between the two biotopes, secondly, seemed sensitive to location site, and finally appeared indifferent to litter species composition effects.

\section{REFERENCES}

AMIGO, J., J., IZCO \& I. ROMERO. 2004. Swamp alder woodlands in Galicia (NW Spain): phytosociological interpretation. Ecological and floristic contrast to western European swamp woodlands and delimitation versus riparian alder woodlands in southern Europe and northern Africa. Phytocoenologia, 34: 613-638. 
BARBARESI, S. \& F. GHERARDI. 2000. The invasion of the alien crayfish Procambarus clarkii in Europe, with particular reference to Italy. Biol. Invasions, 2: 259-264.

BENFIELD, E. F. \& J. R., WEBSTER. 1985. Shredder abundance and leaf breakdown in an appalachian mountain stream. Freshwat. Biol., 15: 113-120.

BRINSON, M. M. \& A. I. MALVÁREZ. 2002. Temperate freshwater wetlands: types, status and threats. Environ. Conser., 29: 115-133.

BRINSON, M. M. 1990. Riverine forests. In: Ecosystems of the world 15: Forested wetlands. A. E. Lugo, M. M. Brinson, \& S. Brown (eds.): 87-141. Elsevier, Amsterdam.

CANHOTO, C. \& M. A. S. GRAÇA. 1996. Decomposition of Eucalyptus globulus and three native leaf species (Alnus glutinosa, Castanea sativa and Quercus faginea) in a Portuguese low order stream. Hydrobiologia, 333: 79-85.

CLARKE, K. R. \& R. N. GORLEY. 2001. PRIMER v5: User Manual/Tutorial. PRIMER-E Ltd. (eds.) Plymouth Marine Laboratory, UK.

CORTES, R. M. V., M. A. S, GRAÇA \& A. MONZÓN. 1994. Replacement of alder by eucalyptus along two streams with different characteristics: differences on decay rates and consequences to the stream functioning. Verh. Internat. Verein. Limnol., 25: 1697-1702.

CRONK, J. K. \& M. S. FENNESY. 2001. Wetland plants: Biology and Ecology. Boca Raton. Lewis publishers. $462 \mathrm{pp}$.

DYNESIUS, M. \& C. NILSSON. 1994. Fragmentation and flow regulation of river systems in the northern third of the world. Science, 266: 753-762.

FERREIRA V., GRAÇA M. A. S., de LIMA, J. L. M. P. \& R. GOMES. 2006. Role of physical fragmentation and invertebrate activity in the breakdown rate of leaves. Arch. Hydrobiol, 165: 493-513.

GALLEGO-FERNÁNDEZ, J. B., R. GARCÍAMORA \& F. GARCÍA-NOVO. 1999. Small wetlands lost: a biological conservation hazard in Mediterranean landscapes. Environ. Conserv., 26: 190-199.

GARLAND, J. L. 1997. Analysis and interpretation of community-level physiological profiles in microbial ecology. FEMS Microbiol. Ecol., 24: 289300.

GESSNER, M. O. \& E. CHAUVET. 1994. Importance of stream microfungi in controlling breakdown rates of leaf litter. Ecology, 75: 1807-1817.
GOMEZ, E., F. FERRERA \& S. TORESANI. 2006. Soil bacterial functional diversity as influenced by organic amendment application. Bioresource Technol., 97: 1484-1489.

GONÇALVES, F. J., J. S. FRANÇA, A. O. MEDEIROS, C. A. ROSA, \& M. CALLISTO. 2006. Leaf breakdown in a tropical stream. Internat. Rev. Hydrobiol., 91: 164-177.

GRAÇA, M. A. S. 2001. The role of invertebrates on leaf litter decomposition in streams-A review. Internat. Rev. Hydrobiol., 86: 383-393.

GULIS, V. \& K. SUBERKROPP. 2003. Interactions between stream fungi and bacteria associated with decomposing leaf litter and different levels of nutrient availability. Aquat. Microb. Ecol., 30: 149157.

GULIS, V., V. FERREIRA \& M. A. S. GRAÇA. 2006. Stimulation of leaf litter decomposition and associated fungi and invertebrates by moderate eutrophication: implications for stream assessment. Freshwat. Biol., 51: 1655-1669.

GUTIÉRREZ-YURRITA, P. J., M. Á., SANCHO, G. BRAVO, Á., BALTANÁS, \& C. MONTES. 1998. Diet of the red swamp crayfish Procambarus clarkii in natural ecosystems of the Doñana National Park temporary fresh-water marsh (Spain). J. Crustacean Biol., 18: 120-127.

HAHN, D. R. 2003. Alteration of microbial community composition and changes in decomposition associated with an invasive interdital macrophyte. Biol. Invasions, 5: 45-51.

HUGHES, J. M. R. 1995. The current status of European wetland inventories and classifications. Vegetatio, 118: 17-28.

HUNER, J. V. \& O. V. LINDQVIST. 1995. Physiological adaptations of freshwater crayfish that permit successful aquacultural enterprises. American Zoologist, 35: 12-19.

INSAN, H. \& M. GOBERNA. 2004. Use of Bio$\log { }^{\circledR}$ for the community level physiological profiling (CLPP) of environmental samples. In: Molecular Microbial Ecology Manual. G. A. Kowalchuk, F. J. De Bruijn, I. M. Head, A. D. L. Akkermans, J. \& D. V. Elsas (eds.): 853-860. Kluwer Academic Publishers. Netherlands.

KAUSHIK, N. K. \& H. B. N. HYNES. 1971. Fate of dead leaves that fall into streams. Arch. Hydrobiol., 68: 465-515.

LECERF, A. P., USSEGLIO-POLATERA, J.-Y., CHARCOSSET, D., LAMBRIGOT, B., BRACHT \& E. CHAUVET. 2006. Assessment of functional 
integrity of eutrophic streams using litter breakdown and benthic macroinvertebrates. Archiv. Hydrobiol., 165: 105-126.

LOCKABY, B. G. \& M. R. WALLBRIDGE. 1998. Biogeochemistry. In: Southern Forested Wetlands. M.G. Messina \& W.H. Conner (eds.): 149-172. Boca Raton. Lewis publishers.

LÓPEZ, E. S., N. FELPETO \& I. PARDO. 1997. Comparisons of methods to study the processing of Alnus glutinosa and Eucalyptus globulus leaves in a forested headwater stream. Limnetica, 13(2): 13-18.

LÓPEZ, E. S., PARDO, I. \& N. FELPETO. 2001. Seasonal differences in green leaf breakdown and nutrient content of deciduous and evergreen tree species and grass in a granitic headwater stream. Hydrobiologia, 464: 51-61.

LUGO, A. E. 1990. Introduction. In: Ecosystems of the world 15: Forested wetlands. A. E. Lugo, M. M. Brinson, \& S. Brown (eds.): 1-14. Elsevier, Amsterdam.

LUGO, A. E., S. BROWN \& M. M. BRINSON. 1990. Concepts in wetland ecology. In: Ecosystems of the world 15: Forested wetlands. A. E. Lugo, M. M. Brinson, \& S. Brown (eds.): 53-85. Elsevier. Amsterdam.

MAIE N., A. BEHRENS, H. KNICKER \& I. KÖGEL-KNABNER. 2003. Changes in the structure and protein binding ability of condensed tannins during decomposition of fresh needles and leaves. Soil Biol. Bioch., 35: 577-589.

MELILLO, J. M., ABER, J. D. \& J. F. MURATORE. 1982. Nitrogen and lignin control of hardwood leaf litter decomposition dynamics. Ecology, 63: 621626.

MESSINA, M. G. \& W. H. CONNER. 1998. Southern Forested wetlands. Boca Raton. Lewis publishers. $616 \mathrm{pp}$.

MILLS, H. A. \& J. B. JONES Jr. 1996. Plant Analysis Handbook II. MicroMacro Publishing Inc. Georgia, USA.

MOLINERO, J. y J. POZO. 2003. Balances de hojarasca en dos arroyos forestados: impacto de las plantaciones de eucalipto en el funcionamiento ecológico de un sistema lótico. Limnetica, 22: 6370.

MOLLÁ, S., L. MALTCHIK y C. CASADO. 1994. Primeros datos sobre el metabolismo de un arroyo torrencial mediterraneo en Sierra Morena (Córdoba). Limnetica, 10: 59-67.
NAIMAN, R. J. \& H. DECAMPS, 1997. The ecology of interfaces: Riparian zones. Annu. Rev. Ecol. Syst., 28: 621-658.

NILSSON, C. \& G. GRELSSON. 1995. The fragility of ecosystems: a review. J. Appl. Ecol., 32: 677692.

OSTROFSKY, M. L. 1997. Relationship between chemical characteristics of autumn-shed leaves and aquatic processing rates. J. N. Am. Benthol. Soc., 16: 750-759.

PASCOAL, C. \& F. CÁSSIO. 2004. Contribution of fungi and bacteria to leaf litter decomposition in a polluted river. Appl. Environ. Microbiol., 70: 52665273.

PASCOAL, C., PINHO, M., CÁSSIO, F. \& P. GOMES. 2003. Assessing structural and functional ecosystem condition using leaf breakdown: studies on a polluted river. Freshwat. Biol., 48: 2033-2044.

PETERSEN, R. C. \& K. W. CUMMINS. 1974. Leaf processing in a woodland stream. Freshwat. Biol., 4: 343-368.

PHAFF, H. J. \& W. T. STARMER. 1980. Specificity of natural habitats for yeasts and yeast-like organisms. In: Biological and Activities of Yeasts. F. A. Skinner, S. M. Passmore \& R. R. Davenport (ed.): 79-101. Academic Press, London.

POZO, J. 1993. Leaf litter processing of alder and eucapyptus in the Agüera strem system (North Spain). Arch. Hydrobiol., 127: 299-317.

POZO, J., A. BASAGUREN, A. ELÓSEGUI, J. MOLINERO, E. FABRE \& E. CHAUVET. 1998. Afflorestation with Eucalyptus globulus and leaf litter decomposition in streams of northern Spain. $H y$ drobiologia, 373/374: 101-110.

RHEINHARDT, R. D., M. C. RHEINHARDT, M. M. BRINSON \& K. FASER. 1998. Forested wetlands of low order streams in the inner coastal plain of North Carolina, USA. Wetlands, 18: 365-378.

RICHARDSON, J. S., C. R. SHAUGHNESSY \& P. G. HARRISON. 2004. Litter breakdown and invertebrate association with three types of leaves in a temperate rainforest stream. Arch. Hydrobiol., 159: 309-325.

RODRÍGUEZ-GONZÁLEZ, P. M., M. T. FERREIRA \& P. RAMIL-REGO. 2004. Northern Ibero-Atlantic wetland woods vegetation types and within-stand structure. Forest Ecol. Manag., 203: 261-272.

SAMPAIO, A., R. CORTES \& C. LEÃO. 2001. Invertebrate and microbial colonisation in native and 
exotic leaf litter species in a mountain stream. Internat. Rev. Hydrobiol, 86: 527-540.

SAMPAIO, A., R. CORTES \& C. LEÃO. 2004. Yeast and macroinvertebrate communities associated with leaf litter decomposition in a second order stream. Internat. Rev. Hydrobiol., 89: 453-466.

SUBERKROPP, K. 1998. Microorganisms and organic matter decomposition. In: River ecology and management: lessons from the Pacific Coastal Ecoregion. R. J. Naiman \& R. E. Bilby (eds): 120143. Springer-Verlag, New York.

TAYLOR, B. R., D., PARKINSON \& W. F. J. PAR-
SONS. 1989. Nitrogen and lignin content as predictors of litter decay-rates-a microcosm test. Ecology, 70: 97-104.

WEBSTER, J. R. \& E. F., BENFIELD. 1986. Vascular plant breakdown in fresh-water ecosystems. Ann. Rev. Ecol. Syst., 17: 567-594.

WIEGERS, J. 1990. Forested wetlands in Western Europe. In: Ecosystems of the world 15: forested wetlands. A. E. Lugo, M. M. Brinson, \& S. Brown (eds.): 407-436. Elsevier, Amsterdam.

ZAR, J. H. 1984. Biostatistical analysis. $2^{\text {nd }}$ Ed. Englewood Cliffs, New Jersey: Prentice Hall. 718 pp. 